\title{
Management Mechanism of Marketing Development Risks for Chinese International Contractors in Saudi Arabia
}

\author{
C. Wang, T.R. Huang \& Y. Liu \\ China Railway Construction Corporation International Group, Haidian District, Beijing, China
}

\begin{abstract}
KEYWORD: Saudi Arabia construction industry; Marketing development risk; Risk management mechanism

ABSTRACT: For achieving the aim of long-term success in executing the "Going-out" strategy, it is essential for Chinese international contractors to manage marketing development risks accurately, effectively and lastingly. A management mechanism and detailed procedure for marketing development risks was developed and applied in Saudi Arabia construction market. Furthermore, marketing development risk register was identified, following by risk analysis including risk importance prioritization and comparative analysis. Accordingly, risk response plan was detailed in response actions according to the project practice attached with necessary risk contingency plan. It could serve as an example for Chinese international contractors to improve risk management mechanism and enhance risk control performance.
\end{abstract}

\section{INTRODUCTION}

Saudi Arabia used to keep the economy growing which benefited from the high income of oil exportation. Saudi government strive to develop infrastructure construction, makes Saudi Arabia becoming the biggest construction market in Gulf Area. This huge market attracted lots of Chinese companies to get involved in market competition (Euler Hermes SA 2016). Among those construction projects, government public projects take the main part of them. In 2013, the awarded government public project contracts value took $65 \%$ of the whole Saudi construction market (China Construction News, 2014). However, because of the impact of a dramatic decrease in oil price, the Saudi government is suffering a big fiscal deficit. This directly leads to uncertain changes in Saudi construction market, bring companies who are running businesses in Saudi Arabia high risks, especially for marketing development risks. In this paper, marketing development risks refer to the possible potential impact on company management and project execution in Saudi construction market because of the uncertain factors which originated from company's external environment, e.g. political, natural and social, economic, industrial, legal and etc.

In recent years, the cases of Chines international contractors suffering heavy losses because of Market Risks - such as Burma hydropower projects being forced to terminate, or unfinished Venezuela high-speed rail projects due to economic recession - are very common. Those losses reflect that Chinese international contractors couldn't manage the marketing development risks effectively, come down to unfamiliarity with national circumstances, social situation, market information, and public opinion of target market countries. Therefore, a effective management mechanism are necessary to be established for well managing marketing development risks and help Chinese international contractors implement projects smoothly and achieve long-term success.

\section{MANAGEMENT MECHANISM}

Establishing a comprehensive long effective risk management mechanism is the premise of guaranteeing the risks to be controlled efficiently. The following works are suggested to be done when establishing the mechanism: 
(1) Setting up management objectives of market risks, emphasizing the awareness of total-staff participation, clarifying the responsible department for each work, and defining the responsibilities and requirements of the auxiliary departments.

(2) Clearly establishing the detailed procedures for the work like Risk Identification, Risk Analysis, Risk Response, etc. Clearly assigning the risk response mechanism for each risk factor based on its analysis result, following up the execution of the risk response plan in order to strengthen risk monitoring and control process.

(3) Creating the database of process document, including Risk Register, Risk Analysis Report, Risk Response Plan, Risk Management Monthly Report and etc., for archiving and accumulating risk data for long-term use.

(4) Strengthening experience summarization and improving management mechanism by keeping updating Market Risk Data through PDCA cycle periodically in every 6 months

The established mechanism is shown in Figure 1.
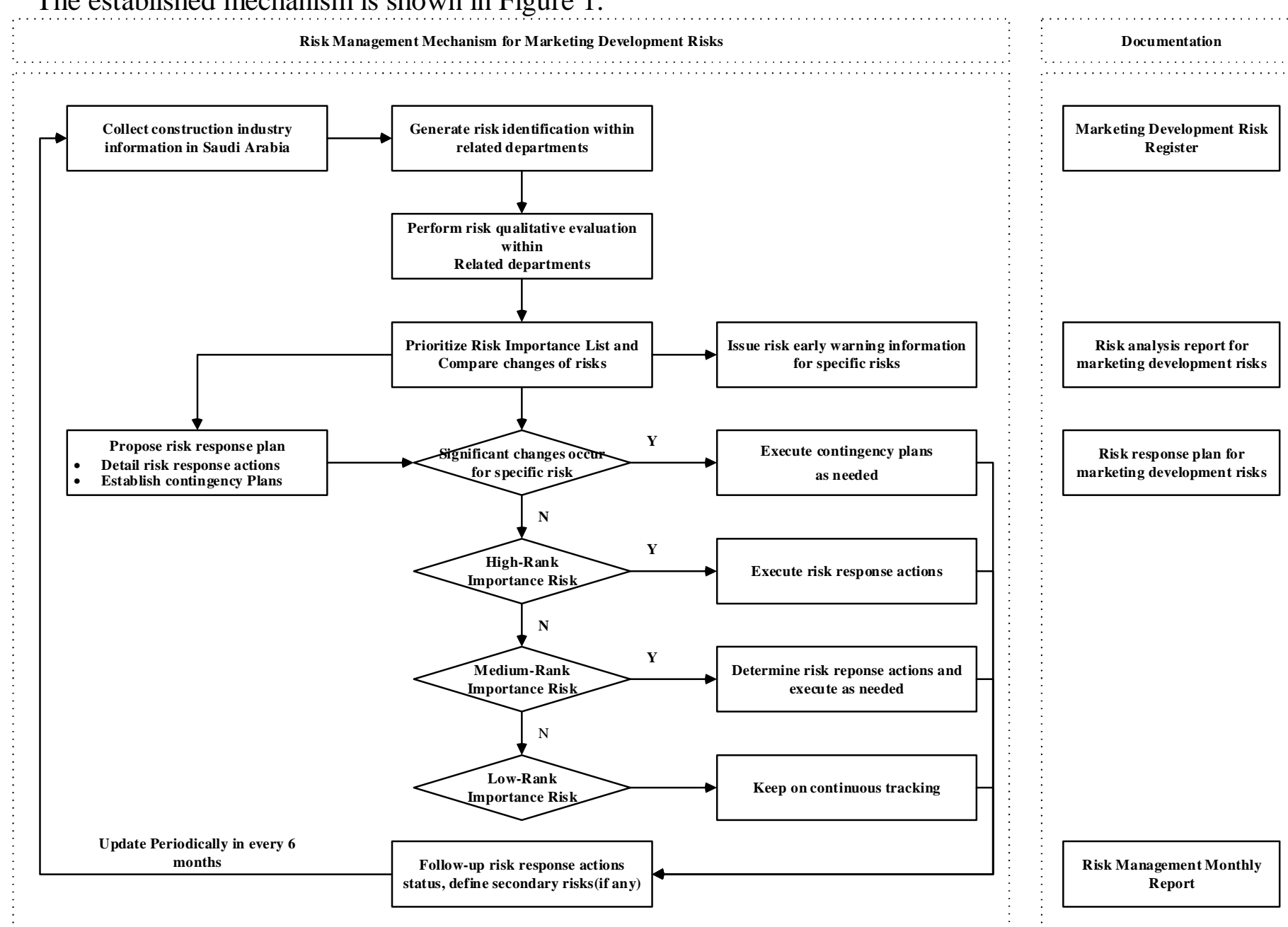

Figure 1. Management Mechanism of Marketing Development Risks

\section{RISK IDENTIFICATION}

To build up the basis of risk management, risk information were gathered and summarized periodically by the marketing department, project-management department in the company level and the teams for the ongoing projects. All the above teams would be organized together and involved in 
identifying potential risks, describing risk details for generating Marketing Development Risk Register, as shown in Table 1 below.

Table 1. Marketing Development Risk Register of Saudi Arabia Construction Markets

\begin{tabular}{|c|c|c|c|}
\hline $\mathrm{No}$ & $\begin{array}{l}\text { Risk } \\
\text { Category }\end{array}$ & Risk Factor & Risk Description \\
\hline $\mathrm{R}_{1}$ & \multirow{7}{*}{$\begin{array}{l}\text { Political } \\
\text { Envi- } \\
\text { ronment } \\
\text { Risk }\end{array}$} & $\begin{array}{l}\text { Political in- } \\
\text { stability risk }\end{array}$ & $\begin{array}{l}\text { Monarch transition, Crown Prince tussle and change of power occurred } \\
\text { during the project execution, which would lead to uncertainty of political } \\
\text { instability }\end{array}$ \\
\hline $\mathrm{R}_{2}$ & & $\begin{array}{l}\text { Unfriendly in- } \\
\text { ternational- } \\
\text { relation risk }\end{array}$ & $\begin{array}{l}\text { Saudi Arabian-led intervention in Yemen led to the country deeply in- } \\
\text { volved in the civil war of Yemen and political tensions on the border } \\
\text { Saudi Arabia broke off diplomatic relations with Iran }\end{array}$ \\
\hline $\mathrm{R}_{3}$ & & $\begin{array}{l}\text { Frequent } \\
\text { change of go- } \\
\text { vernmental } \\
\text { policy risk }\end{array}$ & $\begin{array}{l}\text { The government revise the policy by the law which stipulate public project } \\
\text { would only pay the contractor an advance payment that not exceed } 5 \% \text { of } \\
\text { the contract } \\
\text { The government may pay interim payment for public project by issuing } \\
\text { bonds or i.o.u. }\end{array}$ \\
\hline $\mathrm{R}_{4}$ & & $\begin{array}{l}\text { Governmental } \\
\text { intervene risk }\end{array}$ & $\begin{array}{l}\text { The Contractor may be forced to employ the subcontractors or companies } \\
\text { appointed by the government } \\
\text { The procedures and requirements in different government sectors were } \\
\text { not consistent so that the efficiency is quite low for proceeding }\end{array}$ \\
\hline $\mathrm{R}_{5}$ & & $\begin{array}{l}\text { Discriminato- } \\
\text { ry policy risk }\end{array}$ & $\begin{array}{l}\text { The foreign company in Saudi must employ the specific portion of Saudi } \\
\text { staff. } \\
\text { The foreign company in Saudi may be forced to cooperate with local part- } \\
\text { ner when the ownership ratio of local partner is not less than } 50 \%\end{array}$ \\
\hline $\mathrm{R}_{6}$ & & $\begin{array}{l}\text { Governmental } \\
\text { low-efficiency } \\
\text { risk }\end{array}$ & $\begin{array}{l}\text { The efficiency of the government may be very low due to the adverse fac- } \\
\text { tor, e.g. Ramadan ,eid al-fitr and pilgrimage } \\
\text { The efficiency of settling issues with the government client due to the } \\
\text { complex working procedure and transparent internal processes }\end{array}$ \\
\hline $\mathrm{R}_{7}$ & & $\begin{array}{l}\text { Expropriation } \\
\text { risk }\end{array}$ & $\begin{array}{l}\text { The government would deprive management power from international } \\
\text { companies or projects by forced expropriation, nationalization or related } \\
\text { policies }\end{array}$ \\
\hline $\mathrm{R}_{8}$ & \multirow{3}{*}{$\begin{array}{l}\text { Natural } \\
\text { and So- } \\
\text { cial Envi- } \\
\text { ronment } \\
\text { Risk }\end{array}$} & $\begin{array}{l}\text { Severe natural } \\
\text { condition risk }\end{array}$ & $\begin{array}{l}\text { The construction work on site would be quite hard in Summer which may } \\
\text { reduce the execution efficiency and raise the maintenance cost } \\
\text { The adverse weather, i.e. sandstorm, strong wind and rain storm, may oc- } \\
\text { cur at times }\end{array}$ \\
\hline $\mathrm{R}_{9}$ & & $\begin{array}{l}\text { Social disar- } \\
\text { ray } \\
\text { and unsafe } \\
\text { condition risk }\end{array}$ & $\begin{array}{l}\text { The staff may feel threatened because of social disarray and unsafe condi- } \\
\text { tions } \\
\text { Public security accidents, i.e. theft and rob, may occur on site at times } \\
\text { which would affect the safety of company staff }\end{array}$ \\
\hline $\mathrm{R}_{10}$ & & $\begin{array}{l}\text { Cultural dif- } \\
\text { ference risk }\end{array}$ & $\begin{array}{l}\text { The ideological or business management difference may lead to difficulty } \\
\text { for communication with the Client and the Engineer } \\
\text { The normal working hours may be reduced due to the cultural difference, } \\
\text { e.g. the 5-time Sala for local staff every day. } \\
\text { It may result in communication difficulty or understanding mistake be- } \\
\text { cause of language difference }\end{array}$ \\
\hline $\mathrm{R}_{11}$ & $\begin{array}{l}\text { Econom- } \\
\text { ic Envi- } \\
\text { ronment } \\
\text { Risk }\end{array}$ & $\begin{array}{l}\text { Economic re- } \\
\text { cession risk }\end{array}$ & $\begin{array}{l}\text { The Saudi fiscal deficit soared to the high level due to the slump in oil } \\
\text { prices } \\
\text { The government reduced the investments of public infrastructure, de- } \\
\text { creased the portion of the advance payment and slowed down the interim } \\
\text { payment }\end{array}$ \\
\hline
\end{tabular}




\begin{tabular}{|c|c|c|c|}
\hline $\mathrm{R}_{12}$ & & $\begin{array}{l}\text { Exchange rate } \\
\text { stability risk }\end{array}$ & $\begin{array}{l}\text { The government maintain fixed exchange rate mechanism to U.S. dollar. } \\
\text { Once the fixed rate would be changed into floating rate, it may lead to } \\
\text { huge loss for the project }\end{array}$ \\
\hline $\mathrm{R}_{13}$ & & Inflation risk & $\begin{array}{l}\text { The government may reduce government subsidies for water, electrical } \\
\text { power and even gasoline because of the growing budget deficit } \\
\text { The inflation rate may reach to } 4.5 \% \text { during } 2016 \text { to } 2017\end{array}$ \\
\hline $\mathrm{R}_{14}$ & & $\begin{array}{l}\text { Fluctuation of } \\
\text { taxes and fees } \\
\text { risk }\end{array}$ & $\begin{array}{l}\text { The government may levy new taxes, e.g. the government may levy sale } \\
\text { tax recently } \\
\text { The government may increase the related charge which may increase op- } \\
\text { eration cost }\end{array}$ \\
\hline $\mathrm{R}_{15}$ & \multirow{6}{*}{$\begin{array}{l}\text { Industrial } \\
\text { Envi- } \\
\text { ronment } \\
\text { Risk }\end{array}$} & $\begin{array}{l}\text { Industry entry } \\
\text { risk }\end{array}$ & $\begin{array}{l}\text { In order to obtain Saudi public project, local agents would be employed } \\
\text { by paying } 5 \sim 10 \% \text { commission of the project value }\end{array}$ \\
\hline $\mathrm{R}_{16}$ & & $\begin{array}{l}\text { Special indus- } \\
\text { try conven- } \\
\text { tion risk }\end{array}$ & $\begin{array}{l}\text { The convention in Saudi public project could require the contractor to ac- } \\
\text { cept the agreement template proposed by the government, which may } \\
\text { adopt the FIDIC contract framework but delete the disadvantageous } \\
\text { clauses for the Client } \\
\text { It is quite difficult to withdraw the guarantees which lead to the high ex- } \\
\text { penses on project guarantees }\end{array}$ \\
\hline $\mathrm{R}_{17}$ & & $\begin{array}{l}\text { Labor entry } \\
\text { risk }\end{array}$ & $\begin{array}{l}\text { The Saudi government raise the threshold for the entry of foreign labor in } \\
\text { order to avoid adverse }\end{array}$ \\
\hline $\mathrm{R}_{18}$ & & $\begin{array}{l}\text { Local staff } \\
\text { risk }\end{array}$ & $\begin{array}{l}\text { The ability of local staff employed in Saudi are not sufficient } \\
\text { The local staff act as interest spokesman by stirring up troubles to the } \\
\text { company }\end{array}$ \\
\hline $\mathbf{R}_{19}$ & & $\begin{array}{l}\text { Availability of } \\
\text { local subcon- } \\
\text { tractors and } \\
\text { suppliers risk }\end{array}$ & $\begin{array}{l}\text { The subcontract plan would be proposed in detail because local subcon- } \\
\text { tractors and suppliers could not meet all the requirement of the project. }\end{array}$ \\
\hline $\mathrm{R}_{20}$ & & $\begin{array}{l}\text { Increasingly } \\
\text { severe market } \\
\text { competition } \\
\text { risk }\end{array}$ & $\begin{array}{l}\text { Saudi construction market is a typical buyer's market. Therefore, in order } \\
\text { to obtain project opportunities, the contractor would agree on the unrea- } \\
\text { sonable contract clauses and requirements which could lead to insufficient } \\
\text { profit from the project }\end{array}$ \\
\hline $\mathrm{R}_{21}$ & \multirow[t]{2}{*}{$\begin{array}{l}\text { Legal } \\
\text { Envi- } \\
\text { ronment } \\
\text { Risk }\end{array}$} & $\begin{array}{l}\text { Defective le- } \\
\text { gal system } \\
\text { risk }\end{array}$ & $\begin{array}{l}\text { The Saudi Arabia has a unique legal system based on Islamic Sharia. The } \\
\text { litigation and arbitration must not violate the Sharia laws } \\
\text { The court may have bias or show partiality for the government and local } \\
\text { people. } \\
\text { The proceeding procedure and result may not be estimated accurately. } \\
\text { The efficiency of litigation is low on average }\end{array}$ \\
\hline $\mathrm{R}_{22}$ & & $\begin{array}{l}\text { Legal differ- } \\
\text { ence risk }\end{array}$ & $\begin{array}{l}\text { Unfamiliar with local legal regulations and clauses } \\
\text { Difference of understanding specific laws and regulations due to different } \\
\text { culture and language }\end{array}$ \\
\hline
\end{tabular}

\section{RISK ANALYSIS FRAMEWORK}

Based on the proposed Risk Register, related departments and teams both in the company and project level would be organized to proceed risk analysis work by using qualitative methods such as questionnaires and expert interviews. The main output of risk analysis are separated into the following two parts:

\section{Risk Importance Prioritization}

The assessment of the risk's importance will be got from the common methodology of evaluating indicators of risk's importance in the project management field using questionnaire survey, namely, the 
arithmetic product of the risk's probability of occurrence and its impact if it does occur (Wang C. 2014). The direct output of risk importance prioritization list is shown in Table 2.

Table 2. Risk importance prioritization list (Only high-rank importance risk listed)

\begin{tabular}{|c|c|c|c|}
\hline $\begin{array}{l}\text { No } \\
\text {. }\end{array}$ & Risk Factor & $\begin{array}{l}\text { Mean } \\
\text { value }\end{array}$ & $\begin{array}{l}\text { Stan- } \\
\text { dard } \\
\text { Devia- } \\
\text { tion }\end{array}$ \\
\hline 1 & $\begin{array}{l}\mathrm{R}_{16} \text {-special industry } \\
\text { convention risk }\end{array}$ & 18.95 & 3.83 \\
\hline 2 & $\mathrm{R}_{15}$-industry entry risk & 17.40 & 5.46 \\
\hline 3 & $\begin{array}{l}\mathrm{R}_{6} \text {-governmental low- } \\
\quad \text { efficiency risk }\end{array}$ & 17.28 & 3.64 \\
\hline 4 & $\begin{array}{l}\mathrm{R}_{20} \text {-increasingly severe } \\
\text { market competition } \\
\text { risk }\end{array}$ & 17.24 & 5.14 \\
\hline 5 & $\begin{array}{l}\mathrm{R}_{5} \text {-discriminatory policy } \\
\text { risk }\end{array}$ & 16.64 & 5.48 \\
\hline 6 & $\begin{array}{l}\mathrm{R}_{11} \text {-economic recession } \\
\text { risk }\end{array}$ & 15.12 & 5.98 \\
\hline 7 & $\begin{array}{l}\mathrm{R}_{4} \text {-governmental inter- } \\
\text { vene risk }\end{array}$ & 14.95 & 3.75 \\
\hline 8 & $\begin{array}{l}\mathrm{R}_{3} \text {-frequent change of } \\
\text { governmental policy } \\
\text { risk }\end{array}$ & 13.94 & 4.75 \\
\hline 9 & $\begin{array}{l}\mathrm{R}_{10} \text {-Cultural difference } \\
\text { risk }\end{array}$ & 13.61 & 4.25 \\
\hline 10 & $\begin{array}{l}\mathrm{R}_{8} \text {-Severe natural con- } \\
\text { dition risk }\end{array}$ & 13.17 & 4.81 \\
\hline
\end{tabular}

After the assessment of risk importance prioritization, the level of risk's importance would be defined based on the Risk Matrix (shown in Figure 2). If the risk is located on the right-top (dark-grey) area, its level would be classified as "High". In the same way, the central (light-grey) as "Medium", and left-bottom (white) as "Low". It can be concluded that, all the market risks are located on the high and medium level area, which means the level of Saudi Market Risk is generally high. It should be brought to the forefront of operating management work.

It is observed that the business environment of Saudi construction market is so much different with Chinese construction market. The risk factors, such as the requirements of traditional industry practices, the access restrictions to the foreign companies, discrimination policies and etc., will all bring Chinese international contractors huge risks and unforeseen consequences arising therefrom who are running businesses in Saudi Arabia. Meanwhile, the worldwide economic recession, the failure of the government to pay interim payment caused by the fallen oil price, and the resulting policy risks, etc., are all the essential factors which could impact current business operations deeply. Furthermore, the difference of culture and natural environment between Saudi Arabia and China should also be paid special attention for Chinese international contractors. 


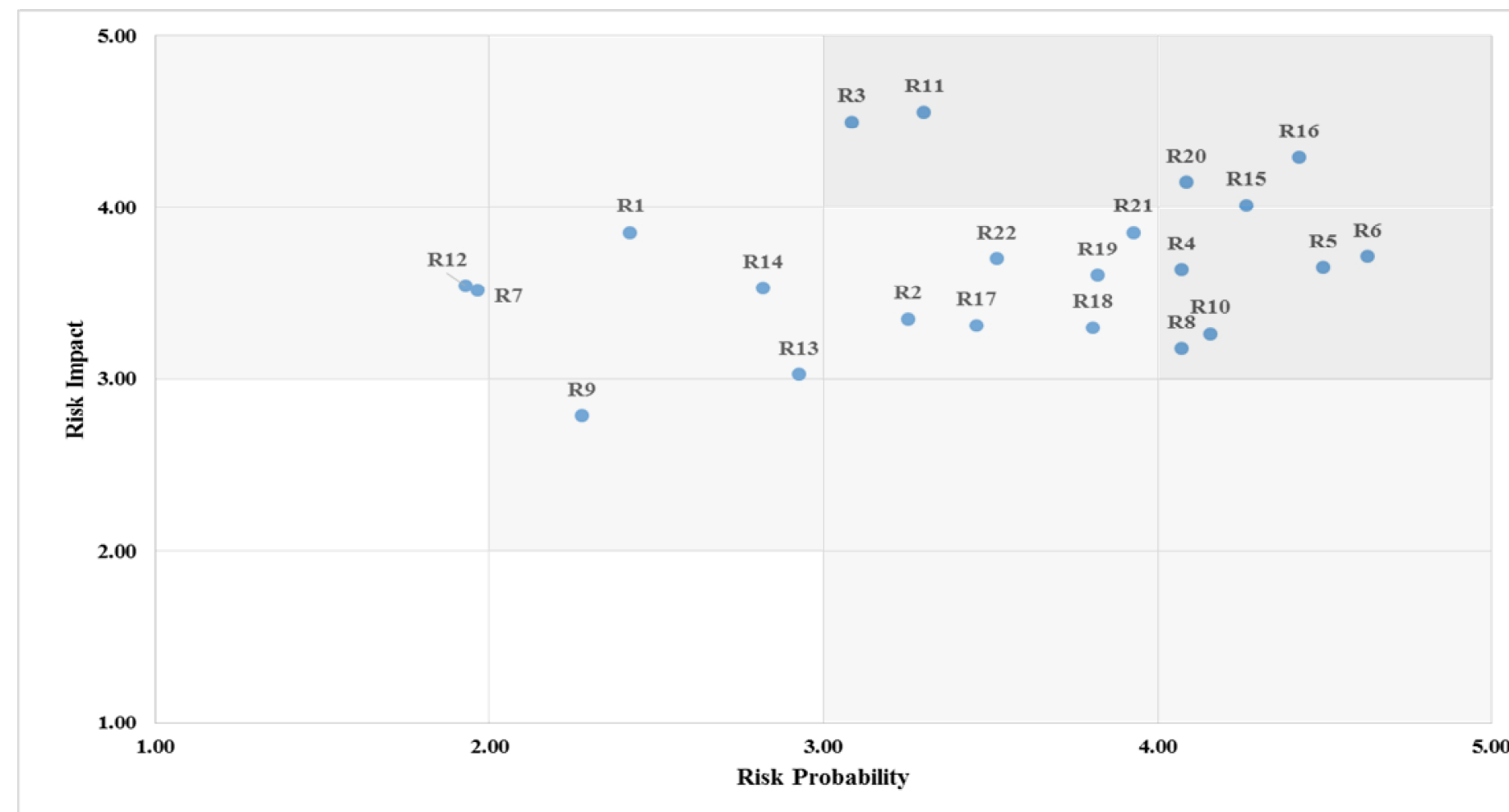

Figure 2. Risk Analysis Matrix of marketing development risks in Saudi Arabia

\section{Comparative analysis on risk change}

Based on risk importance prioritization discussed above, the current period data of risk assessment have been deeply studied. Then, radar-chart methodology would be adopted to compare the relative period assessment result and to analyze the changes of risk factors. The detailed procedure is illustrated in Figure 3, mainly including the following work:

(5) Comparing the changes of risks between current period and previous period. Analyzing the risk period-to-period changes. Identifying the risk factors which had notable changes recently. If significant changes happen, the company should take corresponding measures, and execute the emergency plan for specific risk when it is necessary.

(6) Comparing the changes of risks between current period and benchmark period. Analyzing the risk changes on the fixed base and identifying the risk factors which had notable changes compared with the expectations of the company when it first enter the Saudi market. If significant changes occurred, then related risk early warning information may be issued for specific risk to relative departments of company. Based on the analysis above, the suggestions as basis of decision making would be provided to the company managers for revising company development and operating strategies. 


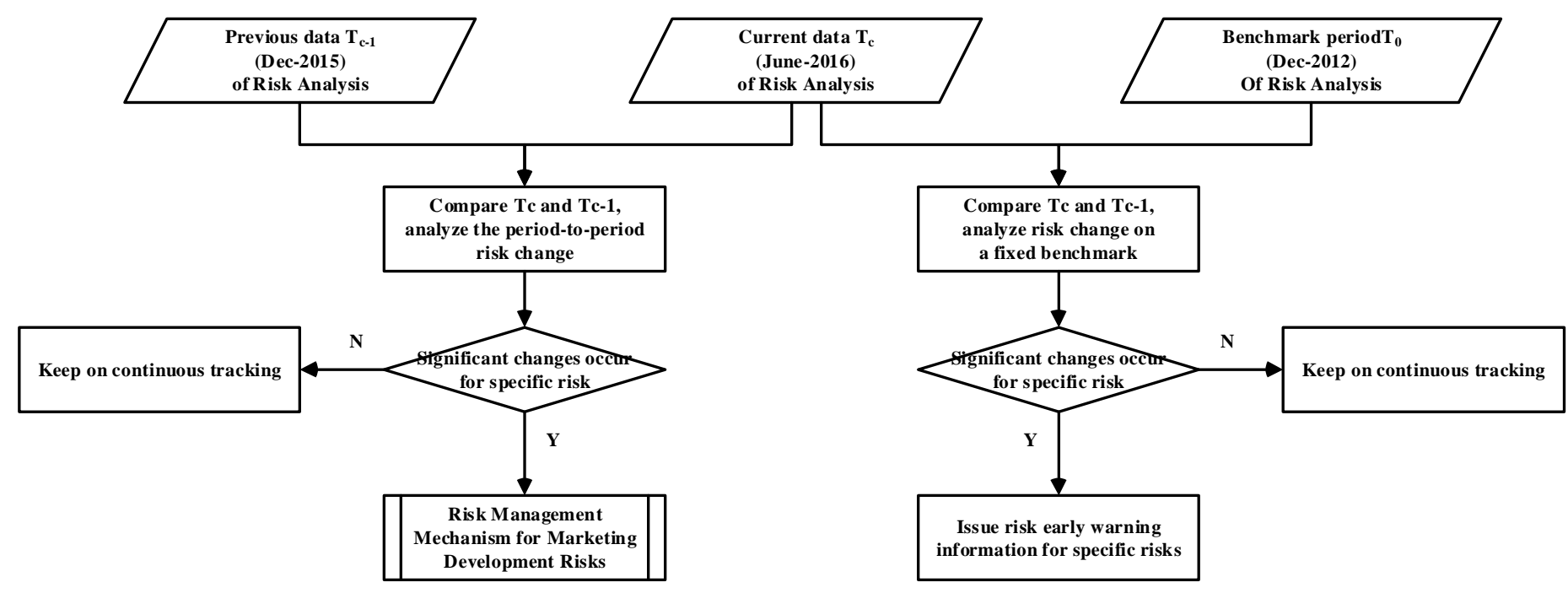

Figure 3. Process of Comparative analysis on risk change

\section{RISK RESPONSE PLAN}

A unified database of risk response plan for marketing development risk were established by the company level. According to the latest risk analysis result, corresponding level are listed as follows:

(7) For the High-rank level, risk response plan would be specified and implemented while risk emergency plan was proposed if necessary.

(8) For the Medium-rank level, risk response plan would be clarified and implemented if necessary.

(9) For the Low-rank level, related department would keep track the status of these risks.

A sample of the risk response plan database (only listing high-rank importance risks) and related response actions are shown in Table 3.

Meanwhile, risk emergency plan for the abovementioned risks would be proposed, including the responsible department, responsibility of related department, and reasonable response actions. Once the risk events occurred due to those risk factors, the company could take necessary actions in time to decrease the negative impact to the minimum. For those risk factors that have significant changes compare with the assessment result, the emergency plan should be activated depending on the circumstances.

Table 3. Risk response plan database (Only High-Rank Importance Risk Listed)

\section{No. $\quad$ Risk Factor}

\section{Risk Response Plan}

Local professional lawyers and experts were employed to deal with negotiations,

Special indus-

$\mathbf{R}_{\mathbf{1 6}}$ try convention risk disputes and claims occurred in the project. Suggestions of company operation and project execution will be proposed by them keep from huge losses resulted by special industry convention (Zheng C.P., 2014)

The team proficient in Saudi Law and convention were established to deal with contract analysis and disputes

Be familiar with the qualification and performance of local agencies through various $\mathbf{R}_{15}$ Industry entry resources in order to determine competitive agents

risk Obligations and duties of the agents would be clarified by studying local laws thoroughly before cooperation with the agents 


\begin{tabular}{|c|c|c|}
\hline $\mathbf{R}_{6}$ & $\begin{array}{l}\text { Governmental } \\
\text { low-efficiency } \\
\text { risk }\end{array}$ & $\begin{array}{l}\text { The application of government business would be executed in advance in order to } \\
\text { avoid the adverse factors(i.e. Ramadan ,eid al-fitr and pilgrimage) } \\
\text { Local agents and staff would be delegated to deal with issues and business concern- } \\
\text { ing on government departments to avoid ineffective communication. } \\
\text { Resources, i.e. the Embassy, Chinese-enterprise association and local agents would } \\
\text { be adopted for better communication with the government. }\end{array}$ \\
\hline $\mathbf{R}_{20}$ & $\begin{array}{l}\text { Increasingly } \\
\text { severe market } \\
\text { competition } \\
\text { risk }\end{array}$ & $\begin{array}{l}\text { Risks would be transferred reasonably to the subcontractors by contract clauses, } \\
\text { which detail specifications and requirements in the Main Contract on the back-to- } \\
\text { back basis }\end{array}$ \\
\hline $\mathbf{R}_{\mathbf{5}}$ & $\begin{array}{l}\text { Discriminato- } \\
\text { ry policy risk }\end{array}$ & $\begin{array}{l}\text { Qualified and eligible local staff were employed to achieve localization and decrease } \\
\text { the cost of saudilization (Liu S.Y., 2011) } \\
\text { Branch office rather than subsidiary was established to avoid shareholder require- } \\
\text { ment of local partner }\end{array}$ \\
\hline $\mathbf{R}_{11}$ & $\begin{array}{l}\text { Economic re- } \\
\text { cession risk }\end{array}$ & $\begin{array}{l}\text { Research on the Client's cash flow arrangement plan was done to avoid abnormal } \\
\text { payment situation and suggest the adjustment on the basis of the original execution } \\
\text { proposal } \\
\text { Cost budget and cash flow plan and follow-up was enhanced both in company and } \\
\text { project level. }\end{array}$ \\
\hline $\mathbf{R}_{\mathbf{4}}$ & $\begin{array}{l}\text { Governmental } \\
\text { intervene risk }\end{array}$ & $\begin{array}{l}\text { Request support from the Client and the End-user to deal with the issues with the } \\
\text { government } \\
\text { Part of the issues involving the government were subcontracted to the local agents } \\
\text { while the key objectives and milestones were clarified for the agents } \\
\text { Local staff who could coordinate with the government were employed and incentive } \\
\text { system was established to encourage their work } \\
\text { Using flexible means of business communication to enhance understanding with the } \\
\text { government officials }\end{array}$ \\
\hline $\mathbf{R}_{\mathbf{3}}$ & $\begin{array}{l}\text { Frequent } \\
\text { change of go- } \\
\text { vernmental } \\
\text { policy risk }\end{array}$ & $\begin{array}{l}\text { Keep concern on local government policies and obtain information in time to prevent } \\
\text { the losses resulted from policy change } \\
\text { Follow up the government policy change in time. In case there is any change that has } \\
\text { an impact on the project, the management team would apply for the Client to revise } \\
\text { the project execution plan to avoid taking the unnecessary cost burden and capital } \\
\text { expense }\end{array}$ \\
\hline $\mathbf{R}_{10}$ & $\begin{array}{l}\text { Cultural dif- } \\
\text { ference risk }\end{array}$ & $\begin{array}{l}\text { International management team was built up while employing local commercial ex- } \\
\text { pert ensure barrier-free communication with the Client and the Engineer } \\
\text { The awareness of the staff on the local customs were strengthened in the training } \\
\text { course by the Chinese Muslim staff }\end{array}$ \\
\hline $\mathbf{R}_{8}$ & $\begin{array}{l}\text { Severe natural } \\
\text { condition risk }\end{array}$ & $\begin{array}{l}\text { Climatic conditions, especially the golden construction period in winter, would be } \\
\text { comprehensively taken into account when generating project execution schedule. } \\
\text { The necessary insurances, e.g. Contractor's All Risks(CAR), were purchased in case } \\
\text { of transferring natural risks which would lead to the loss of the project }\end{array}$ \\
\hline
\end{tabular}

\section{CONCLUSIONS}

To manage marketing development risks more accurately, Chinese international contractors should not only improve the risk management mechanism itself but also need to pay continuous attention to the political situation in Saudi Arabia and gather information in multiple ways. Chinese contractors should keep close contact with the Chinese Embassy, the Economic and Counsellor's Office, in order to achieve mutual benefit and win-win outcome with other Chinese companies. At the same time, continuous attention should also be given to Saudi news media so that the company can obtain information at the first time. Gathering information from other channels, like keeping updating the 
information of the Saudi market from world's major cousultant agencies, or getting advices from agents and the third parties, would all help the company to achieve information-maximization and decision-making optimization during marketing development and projects execution.

To establish a long-term risk management mechanism, besides requesting the awareness of totalstaff participation, it also required risk management mechanism would be intergrated into the comprehensive management framework of the company. In the mechanism, the detailed work obligations, procedures and templates are clarified for the purpose of achieving efficient internal control without adding more workloads. In the meantime, risk management monthly report would be issued and published at regular intervals. It lead more staff to realize the importance of risk management and get involved in the work on their own initiative. A virtuous cycle was generated when dynamically executing and improving risk mangement mechanism.

To manage the marketing development risks efficiently and lastingly, it is essential to build up a localized management team who could be familiar with the environment and circumstances and adapt the management culture of Chinese international contractors. Correspondingly, a reasonable cooperating mechanism should be established to enhance the co-work, integrate resources and have complementary advantages. Meanwhile, the related performance mechanism, which could reach to process evaluation and outcome-motivation, should be adopted to improve the management framework. Base on above, the local staff would truly fit into the Chinese company's team and maximize their performance. It will of high value for Chinese international contractors to overcome oversea marketing development risks and achieve the real localization for long-term success.

\section{REFERENCES}

China Construction News 2014. The volume of Saudi construction output will grow to $\$ 300$ billion by 2015[N].China Construction News, 2014.2.21: 12.

Euler Hermes SA 2016. Country Report-Saudi Arabia [EB/OL]. http://www.eulerhermes.com/economic-research/country-reports/Pages/Saudi-Arabia.aspx

Liu S.Y., 2011. The influence of the unrest in the Middle East for the local construction market [A]. Proceedings of 2011 China-Arab Countries Economic and Trade Forum (V2) [C]: 83-89.

Wang C., 2014. Research of international projects risk early warning system for Chinese international contractors [D]. Beijing: Tsinghua University.

Zheng C.P., 2014. Research of Saudi economic and marketing environment analysis for Chinese enterprises [D]. Shanghai: Shanghai international studies university. 